\title{
Beginning, Developing and Succeeding as a Thai Saxophonist: A Study of Teachers, Performers and the General Public
}

\author{
Pramote Phokha ${ }^{1}$, Sangkom Pumipuntu ${ }^{1}$ \& Rangsiphan Kangkhan ${ }^{2}$ \\ ${ }^{1}$ College of Music, Mahasarakham University, Khamriang Sub-District, Kantarawichai District, Maha Sarakham, \\ Thailand \\ ${ }^{2}$ Faculty of Fine and Applied Arts, Chulalongkorn University, Phaya Thai Road, Pathum Thani District, \\ Bangkok, Thailand \\ Correspondence: Pramote Phokha, College of Music, Mahasarakham University, Khamriang Sub-District, \\ Kantarawichai District, Maha Sarakham 44150, Thailand. E-mail: pphokha147@hotmail.com
}

Received: May 12, 2014 Accepted: May 28, 2014 Online Published: June 12, 2014

doi:10.5539/ach.v6n2p118 URL: http://dx.doi.org/10.5539/ach.v6n2p118

\begin{abstract}
This qualitative research analyses stimuli during three phases in the career of Thai saxophonists. From a purposive sample of six saxophone teachers, six performers and twelve members of the general public, the paper reveals inspirations behind pursuit of a career in the saxophone, requirements for development as a saxophonist and conditions for success. The results show that reasons for starting to play the saxophone are personal interest and love of the saxophone, musical upbringing, friends, lifestyle, admiration of skilled saxophonists and the media. There are six requirements for development: personal characteristics, disciplined practice, good teachers, listening skills, experience and a musical identity. Role awareness and responsibility were the important requirements for success as a saxophone teacher. Successful professional saxophonists perform wholeheartedly to their full potential. Both saxophone teachers and performers must adapt their methods and techniques to the audience.
\end{abstract}

Keywords: saxophone, Thailand, inspiration, development, success

\section{Introduction}

The saxophone was introduced to Thailand at the end of King Vajiravudh's (Rama VI) reign in the 1920s (Amatayakun \& Duangjantip 2007). The saxophone was restricted to marching military bands because Jazz and other modern genres were suffocated by teachers fearing a threat to classical music. Modern music did not gain popularity until the emergence of Western-style bars during the reign of King Prajadhipok (King Rama VII: 1925-35). These new establishments provided the environment for faster styles of music, such as jazz, and permitted incorporation of the saxophone into traditional piano and violin ensembles. From these origins, saxophones became adapted for use in traditional Thai music, including look tung (Thai-country music) and look kung (Thai-city music).

The greatest stimulus for popularising the saxophone among Thai people has been King Bhumibol Adulyadej (King Rama IX: 1946-present), who is an accomplished alto saxophonist. Although the saxophone does not have a long history in Thailand, it has developed rapidly, with particularly important milestones in the last decade. The first Thai-International Composition Competition for Saxophone was held in 2006 and Mahidol University hosted the 15th World Saxophone Congress in 2009. Mahidol University College of Music also organises the International Jean-Marie Londeix Saxophone Competition. The increased domestic and international reputation of Thai saxophonists has resulted in a greater variety and quality of educational establishments providing higher level courses in the saxophone (Jaroensuk, 2005).

These are the views of famous Thai saxophonists regarding their profession in Thailand:

'Professional musicians in the past were not accepted by society as having a real job but love for the saxophone and inspiration from older performers changed the landscape of musical learning' (Sekpon Unsamran, personal communication, 2012).

'To be a good saxophonist, you must practise and listen...it's not all about training your playing ability, you must train your ears too' (Thanit Sriklindee, personal communication, 2012). 
'To have a future as a saxophonist, you must develop your own style and not be an imitation' (Methawat Sapsaenyakorn, personal communication, 2012).

'Experience is the most important form of knowledge for musicians (Yongyut Piwsawan, personal communication, 2012).

From these comments, the most important factor in the development of the Thai saxophonist appears to be the learning process and systematic acquisition of knowledge. Given the significance of musical education, the research team wished to analyse the perceptions of teachers, performers and the general public regarding inspiration to become a saxophonist, requirements for professional development and conditions for success.

\subsection{The Philosophy of a Saxophonist}

Sukree Jaroensuk (2002) suggests that practice is at the heart of a good musician. According to Jaroensuk, it is imperative that the saxophonist systematically plans training objectives and methods (Hiranrak, 2009). Performance is the highest of these objectives and must be carried out wholeheartedly to the best of the artist's ability. The performer must therefore be a principled individual (Baker, 1981; Jaroensuk, 2006). Each experience adds to the performer's catalogue of knowledge, so performance must be used to showcase existing ability and develop new methods (Russell, 2010). A philosophy or paradigm is a collection of concepts, values, perceptions and practice of a group or individual (Kairmanee et al., 2002; Kakai, 1997). The musical philosophy of Sukree Jaroensuk is one of continual development (Jaroensuk, 2005). Jaroensuk identified a series of new trends in Thai music, eleven in total: new music, new audiences, new atmospheres, new culture, new performers, new generations, new locations, new compositions, new life, new professionalism and new power. The dynamism of modern Thai music was also a consideration during the organization of the 2010 International Jazz Festival (Buranawitayawut, 2010). In a recent analysis of traditional Isan music, Pattana Kitiasa (2010) noticed an increase in musical experimentation and integration of non-musical media during stage performances to maintain the interest of modern audiences. Despite the need for change, it is important that the founding principles of the music remain and that it stays compatible with the performer and culture (Premanon, 2010).

Learning is the development of knowledge that comes from adaptation of behaviour and training and has two phases: process and outcome (Kairmanee et al., 2002). In her learning theory, Tisana Kairmanee, in agreement with the basic concept of Jean Piaget's cognitive development, suggests that the learner must be at the appropriate stage of physical, intellectual, social and mental maturity and must have motivation to study (Kairmanee et al., 2002; Kowtrakool, 2005; Piaget, 1973). Traditionally, the Thai education system is based on the principles of behaviourism, whereby learning is achieved through behavioural conditioning (Lasuwong, 1985). This is achieved in both the classical and operant senses. Increasingly though, Thai education has adopted the active learning of Jerome Bruner's cognitive psychology and placed emphasis on teaching methods that are appropriate for the audience (Bruner, 1960; Office of the National Education Commission, 1997). Narut Suttijit (1998) argues that these institutional developments are not enough, as learning, especially musical learning, is reinforced in the familial and social environment. The household and community stimulate attention, retention, reproduction and motivation (Pumin, 2004). These concepts were confirmed by Weerapon Saengpanya (2004) in a case study of creative thinking and performance in Thai sciences, arts and education.

Paitoon Patyaiying (1998), Suchat Suti (2000) and Suchaow Ploychum (1991) also argue that musical success depends on the aesthetical value of the performance for the audience, subjectively, objectively and relatively. Consequently the aim of musical instruction must be to train the artist to recognise the aesthetical requirements of the audience and reproduce those requirements to the best of their ability (Suttijit, 1998).

\section{Methodology}

This is a qualitative research analysing the concepts of saxophone-playing as a profession. The research sample was purposively selected and divided into three groups: teachers, performers and the general public. Six teachers were selected based on the criteria that they had graduated from a musical degree with a major in classical or jazz saxophone and taught practical music at a higher education institution. Three classical saxophonists and three jazz saxophonists were chosen. Six performing musicians were selected. The musicians had either developed their saxophone skills from education or independently and they played solo or as part of a band. Twelve members of the general public were selected, including one student of each of the teachers in group one and one member of the audience at performances of each of the performers in group two. The research area was composed of performance venues and higher education institutions teaching practical music instruction in Bangkok. The universities chosen were Mahidol, Chulalongkorn, Silpakorn, Kasetsart and Rangsit. The research period was one year from April 2012. 
Data for this investigation was collected from document analysis and field research. Data collection methods were survey, interview and observation. Personal information on each of the informants was gathered by survey. Each respondent group was interviewed in two parts. The first part of the interview was designed to gather personal information about the respondent. The second part of the interview was divided into three sub-sections: thoughts on inspiration to learn the saxophone, thoughts on musical development and thoughts on musical success. Unstructured interviews were conducted to supplement the structured versions by asking respondents to provide information on musical philosophy, daily life, performance techniques, training methods and professional obstacles. Additional data was recorded during participant observation, whereby the research team observed teaching, performing and learning in each of the three groups.

Collected data was arranged according to the research aims in three categories: reasons for starting to play the saxophone, requirements for development as a saxophonist and conditions for success. The data was validated using a triangulation method. Four types of triangulation were employed according to the methods of Supang Chantavanich (2002). Firstly, the data was validated by time and place to see if data collected at different times, different places and from different people yielded the same results. Secondly, the data was tested to see if different researchers gathered similar results. Thirdly, the research data was examined to determine how different theoretical applications affected the results. Finally, results obtained from different methods were compared to identify discrepancies. Once validation had been completed and anomalies re-investigated, the information in the three categories was summarized before analysis. Two methods of analysis were used: typological analysis and analytic induction (Chantavanich, 2002). The typologies or data sets were the categories previously described: reasons for starting to play the saxophone, requirements for development as a saxophonist and conditions for success. From these categories, analytic induction was used to find similarities and differences between data provided by each respondent group (Taylor \& Bogdan, 1998; Znaniecki, 1934). The data is presented as a descriptive analysis.

\section{Results}

The results of this research are divided by respondent group.

\subsection{Musical Perspectives of Saxophone Teachers}

Two groups of saxophone teachers were included in this study, classical and jazz. Nattha-orn Laowongpiernput (personal communication, 2012), a classical saxophone teacher, explained that 'there are four reasons for my interest in higher-level music: personal interest driven by school musical performances, the actions of my role model King Bhumibol Adulyadej, family support and my admiration for skilled performers.' Laowongpiernput added that her decision for pursuing a career in music was made after having been given an opportunity to try out teaching and her courage developed from that experience. Classical saxophonist Wisuwat Preuksawanit (personal communication, 2012) wanted to play music with his friends. He chose the saxophone because he liked the sound and few people are able to play it well. He chose to play in the classical style because that would get him into the school marching band and he did not understand the concept of jazz. Additionally, classical saxophone was not popular and he wanted the chance to help make it famous. Lakkachai Kreutnoi (personal communication, 2012) accredited his interest in classical saxophone to the influence of friends and his enjoyment in trying out the instrument. 'You get more acclaim from being a classical musician.' This was Kreutnoi's response when asked why he chose the classical school.

Krit Buranaeitayawut's (personal communication, 2012) interest in jazz saxophone came from watching his school marching band, admiration for clarinet players and the advice of friends. Manop Waronitipat (personal communication, 2012), a jazz saxophone teacher, believes that his interest in music was stimulated by a musical environment in his family, which provided him with an opportunity to listen to and see saxophone performances. He chose to be a saxophone teacher because it is the highest level of musical performance, it is a stable occupation and he was encouraged by friends in the profession. Another jazz saxophone tutor, Pisut Prateepasen, had this to say:

'My family had both a direct and indirect influence on me starting to play the saxophone. They actively supported my interest by buying my first instrument and encouraging me to take up music but my interest itself was probably fuelled by my family's love of music. There was also a band at my father's workplace. My interest was really cemented when I went to watch jazz concerts. I wanted to have the same ability and aura that the performers had.' (Pisut Prateepasen, personal communication, 2012)

When asked about the requirements for personal development as a saxophonist, Nattha-orn Laowongpiernput (personal communication, 2012) responded that 'the first thing you need is to be a good person.' She reasoned that one must be a dedicated and focused individual to hone one's musical skills. In this respect, a good 
saxophonist is made by their upbringing if they 'are supported by their family, and instilled with strong personality characteristics and a sense of responsibility' (Nattha-orn Laowongpiernput, personal communication, 2012). These 'strong personality characteristics' were further explained by Wisuwat Preuksawanit (personal communication, 2012) as organization, discipline, creativity and high auditory processing ability. 'The ability to hear and translate musical sounds is a skill best developed from a young age. 'Development of higher learners should focus on three skills: discipline, hearing and critical thinking' (Lakkachai Kreutnoi, personal communication, 2012).

Jazz teacher Krit Buranaeitayawut felt that a saxophonist can come from any background but four traits are necessary for development as a higher-level player: love for music, perseverance, concentration and consideration (Krit Buranaeitayawut, personal communication, 2012). Pisut Prateepasen (personal communication, 2012) also emphasised the importance of advanced listening skills, especially when analysing the rhythm section of music. Of equal importance to Prateepasen were a unique and identifiable tone that distinguishes the saxophonist and an understanding of how to advance as a player. Manop Waronitipat (personal communication, 2012), felt that there were five areas that a good saxophonist must develop: love for music, continuous training, listening skills, self-discipline and practical experience.

'Everyone can be a music teacher but to be a successful music teacher you must be principled, responsible, aware, dedicated and organised' (Nattha-orn Laowongpiernput, personal communication, 2012). According to Wisuwat Preuksawanit (personal communication, 2012), the objectives of any saxophone teacher are twofold: 1) 'to encourage the students to love music and inherit a musical purpose and direction'; 2) 'to teach a foundation of theories and practical techniques to the student.' Preuksawanit also emphasised the importance of student-centred learning approaches, professional integrity and role-model behaviour. 'Teachers are like doctors. They must observe patients (pupils) and diagnose their problems. Consequently, the treatment (teaching methods) will differ from one person to the next.' (Lakkachai Kreutnoi, personal communication, 2012). Each of the respondents claimed that a successful teacher is one who shows dedication to their profession, honesty to their students and varies their methods of instruction. A good teacher must also be punctual and strike a close working relationship with their students. This was something that came easy for Lakkachai Kreutnoi in his first eight years of teaching because he was a similar age to his students. 'In the last ten years it has been more difficult. I can solve the problem of age by eating with my students and playing music together with them' (Lakkachai Kreutnoi, personal communication, 2012).

Before Krit Buranaeitayawut became a music teacher, he graduated as an architect. He believes the disciplines to be similar. 'An architect must create structures suitable to their environment, so a teacher must analyse their students' abilities, behaviours and hopes for the course before they teach' (Krit Buranaeitayawut, personal communication, 2012). In the opinion of Pisut Prateepasen (personal communication, 2012), effective teaching comes from consideration of and adaptation to the needs of individual learners. 'The teacher must understand that each pupil is different and the teaching material must reflect this' (Manop Waronitipat, personal communication, 2012).

Conclusions made from interviews with teachers on the reasons for starting to play the saxophone, ways to develop as a saxophonist and indicators for success are summarised in table 1 (Table 1).

Table 1. A summary of teacher interview results

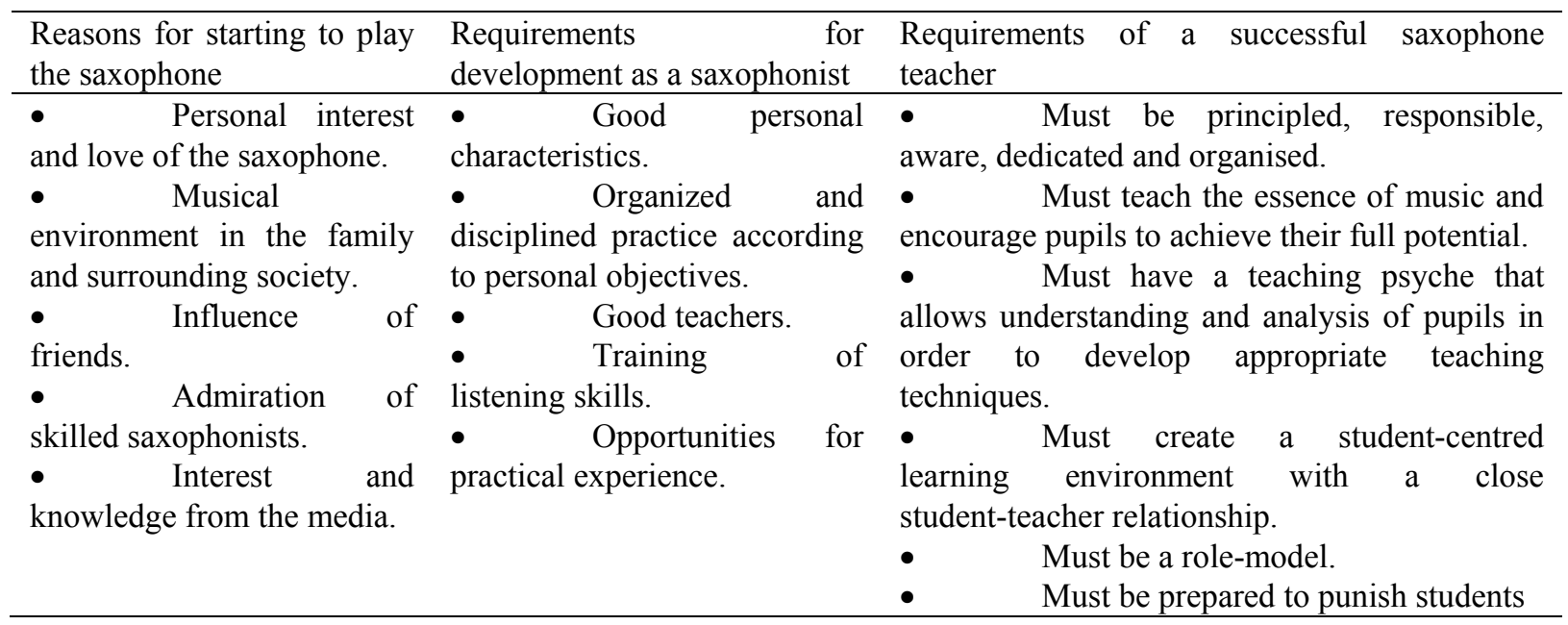




\subsection{Musical Perspectives of Performing Saxophonists}

Professional saxophonist Methawat Sapsaenyakorn (personal communication, 2012) drew his inspiration from a very supportive family. 'My family were musical and keen for me to pursue something I loved that I could do with my own hands, so they gave me experience and knowledge in music.' His love for the saxophone came from the sound and an understanding that the saxophone was an important component of bands. Yongyut Piwsawan (personal communication, 2012) identified two factors that drove him towards a musical career: his home environment and King Bhumibol Adulyadej. 'My own interest in the saxophone came from listening to the sound of the instrument and seeing the part it played in local bands. I love the sound it makes! As far as my decision to choose the jazz saxophone, I loved the sound of Benny Goodman and Lester Young' (Wichai Eung-Amporn, personal communication, 2012). Thanit Sriklindee (personal communication, 2012) identified three influences for his choice to take up music as a career. The first influence was his interest in music, generated by a love of the saxophone sound, his family environment and a chance he was given to learn about the modern musicale. The second influence was professional benefits. 'Professional musicians can earn three or four times more than a music teacher,' a teacher must dedicate their time to theory and administration as well as practice and playing, 'and I just love playing too much!' The third influence was the popularity of the saxophone and ease of finding work. Pusit Laitong (personal communication, 2012) became interested in the saxophone after seeing King Bhumibol Adulyadej and other bands play on the television and hearing them on the radio. 'I also heard Suntaraporn introduce Western music to Thailand and saw the winners of the national marching band contest from Wat Suthiwararam School. They were my inspirations.' The sixth saxophonist interviewed, Sekpon Unsamran, identified his private interest, support from his family and his music teacher as having the largest influences on his pursuit of a professional music career (Sekpon Unsamran, personal communication, 2012).

Yongyut Piwsawan (personal communication, 2012) said that musical ability includes patience and a good musical instrument. Aside from musical ability, Methawat Sapsaenyakorn (personal communication, 2012) names identity and creativity as the two most important areas that a performing artist must develop. Piwsawan was in agreement, saying 'if you want to be a good musician, you must first copy your teacher. Once you have perfected his style, you must then make it your own' (Yongyut Piwsawan, personal communication, 2012). Wichai Eung-Amporn (personal communication, 2012) also saw the need to develop an individual musical identity but also felt that behavioural characteristics were the keys to musical development, such as honesty, professionalism and responsibility. Thanit Sriklindee (personal communication, 2012) placed great importance on the development of musical hearing and training of listening skills. 'Musical training is much the same as practising doctrine, we must concentrate our mind on the thing we are doing, then our ears will hear every sound' (Pusit Laitong, personal communication, 2012). Sekpon Unsamran (personal communication, 2012) named five things that a saxophonist must have: familiarity with their instrument; knowledge of saxophone sound quality; knowledge of saxophone styles throughout history; dedication to learning the musical world and making their own music international; creativity.

To be a successful musician, one must adapt one's music to the audience (Methawat Sapsaenyakorn, personal communication, 2012). This is achieved by performance planning (Wichai Eung-Amporn, personal communication, 2012). According to Yongyut Piwsawan (personal communication, 2012), it is the aim of every musician to perform. In light of this, he said that the performance must reveal the full scope of the artist's ability. Skilled artists who play wholeheartedly will achieve success (Thanit Sriklindee, personal communication, 2012). 'So long as the artist plays to the best of their ability and the audience enjoys the performance, the saxophonist will achieve success' (Pusit Laitong, personal communication, 2012). Sekpon Unsamran (personal communication, 2012) concluded four requirements for success as a saxophonist: inheritance, individual performance style, relationship with the audience and performance planning.

Conclusions made from interviews with performers on the reasons for starting to play the saxophone, ways to develop as a saxophonist and conditions for success are summarised in table 2 (Table 2).

By combining the results from teachers and performers it is possible to summarise reasons for starting to play the saxophone as personal interest and love of the saxophone, musical environment in the family and surrounding society, influence of friends, lifestyle, admiration of skilled saxophonists and interest and knowledge from the media. There are six common requirements for development as a saxophonist: suitable personal characteristics and ability; organised, guided and disciplined practice; good teachers; training of listening skills; practical experience; creation of a unique personal musical identity. Although the specific details given by respondents in the two groups were different, there were two clear categories of thought regarding requirements for success as a saxophonist. The first category was concepts of teaching and performing. Teachers felt that role awareness and responsibility were the important requirements for success as a teacher. Professional musicians considered 
performing wholeheartedly to one's full potential as the greatest condition for success. The second category was psychological foundations in teaching and performing. Teachers saw the need to adapt teaching methods and techniques to the learner. Similarly, performers highlighted awareness of the audience and adaptation to meet their needs as primary concerns.

Table 2. A summary of performer interview results

\begin{tabular}{|c|c|c|}
\hline $\begin{array}{l}\text { s for starting to play } \\
\text { ophone }\end{array}$ & $\begin{array}{l}\text { Requirements for } \\
\text { development as a saxophonist }\end{array}$ & $\begin{array}{l}\text { Requirements of a successful saxophone } \\
\text { performer }\end{array}$ \\
\hline $\begin{array}{l}\text { Personal interest and love of } \\
\text { the saxophone. } \\
\text { Musical environment in the } \\
\text { family and surrounding } \\
\text { society. } \\
\text { Lifestyle. } \\
\text { Admiration of skilled } \\
\text { saxophonists. } \\
\text { Interest and knowledge from } \\
\text { the media. }\end{array}$ & $\begin{array}{l}\text { Patience and hard-work. } \\
\text { Dedication and a 'musical } \\
\text { spirit'. } \\
\text { A high-quality musical } \\
\text { instrument. } \\
\text { Training of performing and } \\
\text { listening skills. } \\
\text { Creativity and unique musical } \\
\text { identity. }\end{array}$ & $\begin{array}{l}\text { Performance to full potential. } \\
\text { Dedicated and committed performance. } \\
\text { Adjustment of performance to suit the } \\
\text { audience. } \\
\text { Performance strategy, including exhibition of } \\
\text { full range of abilities, staging, creation of a } \\
\text { relationship with the audience and } \\
\text { performance planning. }\end{array}$ \\
\hline
\end{tabular}

\subsection{Musical Perspectives of the General Public}

According to members of the general public, causes for interest in music are a desire to play, personal fondness for certain musical sounds, the surrounding familial and social environment and admiration for skilled performers. The general public felt that a saxophonist must possess and develop seven characteristics: love for the saxophone; skill in playing the saxophone; good hearing; multiple playing styles and techniques; readiness for continual learning; good human relations; creativity. The image of a successful saxophone teacher for the general public was a responsible role-model with a variety of teaching techniques, an ability to adapt to the environment and a patient teaching mentality. The image of a successful saxophone performer for the general public was a professional, responsible and skilled musician with good human relations, an ability to adapt to the environment and a willingness to continually learn.

\section{Discussion}

The desire to study the saxophone derives from a personal interest in the instrument. An important factor in stimulating this interest is the environment within the household and local society. This can affect musical interest directly and indirectly. Particularly influential are familial music preferences. Schools can have a pivotal role in developing musical interest by providing students with opportunities to perform and be exposed to different musical genres. These impulses generate interest and love for music in later life. This notion corresponds to the Kairmanee's learning theory, whereby learners must be ready to study in terms of physical, intellectual, social and mental maturity (Kairmanee et al., 2002). The level of student readiness depends on training, experience and interest. Moreover, interest in learning goes a long way towards building educational success. As interest comes from the family and society, they are indirect causes of educational success. Additional factors in student success are the environment, teachers, study materials and teaching methods. This agrees with the research of Prapansak Pumin (2004), which concerned factors leading to the success of violin instruction. Pumin found that households have an influence on the personal characteristics, learning environment, media access and learning materials of violin students. Playing family members, household access to violin music and family trips to concerts also aroused the interest of violin students. Weerapong Saengpanya (2004) found that creative people have characteristics and work in environments that are favourable to development. Saengpanya noted that creativity either comes from adversity or inspiration.

Good saxophonists must have good character traits and love music, especially the saxophone. Training must be systematic, disciplined and ongoing. Particular emphasis should be placed upon hearing and listening skills. Ultimately the saxophonist must play with a unique tone and develop an individual artistic identity. These findings are in agreement with Sukree Jaroensuk (2006), who argued that good musicians must be both skilled and principled. Jaroensuk theorised that a principled person will possess all of the desirable characteristics diligence, dedication and discipline - to be a good learner and develop into a skilled player. A successful saxophonist must first plan their studies and outline challenging, yet attainable study goals. Principled students, 
so Jaroensuk concludes, will achieve these objectives.

Results of this study show that the performers and teachers must develop a relationship with their audience and adapt their style accordingly. This is concurrent with the aesthetics theory of Paitoon Patyaiying (1998). Patyaiying suggested that aesthetical preferences depended upon the value of the performance for the audience. The value in turn depends on the characteristics of the audience, which makes it especially important that the artists play to suit their listeners.

\section{Conclusion}

This research is a valuable source of information that can be used by the Thai ministry of education and saxophone teachers at higher education institutions to adapt higher education saxophone curriculums. The results indicate that practical saxophone teaching approaches must be student-centred and responsive. Greater emphasis must be placed on personal characteristics of prospective saxophone students and the development of a unique musical identity. Additionally stage performers must create a relationship with their audience and plan their routine to maximise its value to the listeners.

\section{References}

Amatayakun, P., \& Duangjantip, S. (2007). Thai Jazz bands before World War II [in Thai]. Music Journal, 12(9), 25-35. Nakhon Pathom: Mahidol University.

Baker, P. J. (1981). The development of music teacher checklists for use by music supervisors and teachers in evaluating music teaching effectiveness. Unpublished doctoral thesis, University of Oregon.

Bruner, J.S. (1960). The process of education. Cambridge, MA: Harvard University Press.

Buranawitayawut, K. (2010). Thailand International Jazz Conference 2010 (TIJC 2010): Jazz learning for social enjoyment [in Thai]. Music Journal, 15(5), 15-17.

Chantavanich, S. (2002). Qualitative research method [in Thai]. Bangkok: Chulalongkorn University Press.

Hiranrak, S. (2009). Active reading: A review of teacher training processes in Thai music education [in Thai]. Music Journal, 15(4), 64-67. Nakhon Pathom: Mahidol University.

Jaroensuk, S. (2002). The art of saxophone playing [in Thai]. Bangkok: Hanghunsuwan.

Jaroensuk, S. (2005). The new face of music in Thailand [in Thai]. Music Journal, 11(5), 25-30.

Jaroensuk, S. (2006). Problems and separation in Thai music education [in Thai]. Music Journal, 12(3), 88-91.

Kairmanee, T., et al. (2002). The science of teaching [in Thai]. Bangkok: Chulalongkorn University Press.

Kakai, K. (1997). The psychology of teaching [in Thai]. Bangkok: 9119 Technik Printing.

Kitiasa, P. (2010). Isan music: labour, feeling and displacement [in Thai]. People, music, life: The sounds of Thailand (Vol. 2). Bangkok: Sirinthorn Institute of Humanities.

Kowtrakool, S. (2005). Psychology of education (5th ed.) [in Thai]. Bangkok: Chulalongkorn University Press.

Lasuwong, K. (2002). Psychology of education. Bangkok: Srinakharinwirot University Press.

Office of the National Education Commission. (1997). Participatory learning theories: A model of learning in theory and practice [in Thai] .Bangkok: Idea Square.

Patyaiying, P. (1998). Aesthetics: Concepts, theories and problems [in Thai]. Bangkok: Sematham Printing.

Piaget, J., \& Inhelder, B. (1973). Memory and intelligence. London: Routledge and Kegan Paul.

Ploychum, S. (1991). Aesthetical problems and theories of beauty and art [in Thai]. Bangkok: Mahamakut Buddhist University Press.

Premanon, W. (2010). Music for the development of Thai pianists' potential [in Thai]. Rangsit Music Journal, $5(2), 5-19$.

Pumin, P. (2004). Factors leading to the success of violin instruction [in Thai]. Unpublished doctoral thesis, Mahidol University, Thailand.

Russell, B. E. (2010). The empirical testing of a musical performance assessment paradigm. Unpublished doctoral thesis, University of Miami.

Saengpanya, W. (2004). Characteristics, creative thinking processes and creative performance results: A case study of creative Thai people with prominent results in the sciences, arts and education [in Thai]. Unpublished doctoral thesis, Chulalongkorn University, Thailand. 
Suti, S. (2000). Aesthetics of life [in Thai]. Bangkok: Sematham Printing.

Suttijit, N. (1998). The psychology of music teaching [in Thai]. Bangkok: Chulalongkorn University Press.

Taylor, S. J., \& Bogdan, R. (1998). Introduction to Qualitative Research Methods. New York, NY: Wiley.

Znaniecki, F. (1934). The method of sociology. New York, NY: Farrar \& Rinehart.

\section{Copyrights}

Copyright for this article is retained by the author(s), with first publication rights granted to the journal.

This is an open-access article distributed under the terms and conditions of the Creative Commons Attribution license (http://creativecommons.org/licenses/by/3.0/). 